じく第3㘡の如くなる．混合比が $100: 0 か ら 75: 25 に$ 移る間で各イオンの移動度，分離椇位が大きく变化して いる.

ここにしめした例の如く，一般に2 溶媒の混合比をか えることによって，各種イオンの分離状況を变化せしめ る分離法が考えられる.

以上 $\mathrm{CH}_{3} \mathrm{OH}$, Aceton を使用する方法により，水溶 液の場合と異った分離状況が得られたが，特に水溶液の 第 3 報3) の場合では分離困難であった, $\mathrm{Sr}^{++}$と $\mathrm{Ba}^{++}$ および $\mathrm{Ni}^{++}, \mathrm{Co}^{++}, \mathrm{Mn}^{++}$等と $\mathrm{Zn}^{++}$の分離が可能で あった。

\section{総括}

有機溶媒使用の例として, $\mathrm{CH}_{3} \mathrm{OH}$ および Acetonの 場合について一応の知見を得た。すなわち

(1) $0.005 \mathrm{M} \mathrm{NH}_{4} \mathrm{Cl}-100 \mathrm{cc} \mathrm{CH}_{3} \mathrm{OH}$ 中に抏いての分 離は本交にしめす如くで，各イオンの斑点はまとまった 形で得られ，各イオンは滤紙上で，ほぼ一定の移動度を もち，混合した場合はその移動度の順位で分離される。

(2) $\mathrm{CH}_{3} \mathrm{OH}$ あるいは Aceton $100 \mathrm{cc}$ に $1 \mathrm{NHCl} 5 \mathrm{cc}$ 添加の箩合も上と同じくまとまった斑点が得られ，本交 にしめしたイオンの例では Aceton 中の方が $\mathrm{CH}_{3} \mathrm{OH}$ 中 より 多移動度が一般に大きく, Aceton 中と $\mathrm{CH}_{3} \mathrm{OH}$ 中
では移動順位が異る。

(3) $\mathrm{CH}_{3} \mathrm{OH}$ と Aceton の容量比をかえると，イオン の分離状洗が变化する. 特に $\mathrm{CH}_{3} \mathrm{OH}$ : Aceton $100: 0$ から $75: 25$ の範国で大きく变化する.

(4) $\mathrm{CH}_{3} \mathrm{OH}$ あるいは Aceton $100 \mathrm{cc} に 2 N \mathrm{HCl} 5 \mathrm{cc}$, または $\mathrm{HCl}$ ガスを吹込んで無水の状態でおこなった場 合はいずれも，斑点が流れるので分離の目的には適さな いことを認めた。

(5) $\mathrm{CH}_{3} \mathrm{OH}$, Aceton 両液の場合共, その溶媒中の移 動度より, 濾紙上の移動度はかなり小さく, イオンの滤 紙への吸着が大きいことが推察された。

研究に当り御指導御助言を戴いた東京工業大学教授植 村环先生, 同岩崎岩次先生, 金沢大学柴田村治氏に嬮く感 謝いたします。なお熱心に実験を援助された園山礼子氏 に深謝致します.（昭和 29.4.3 日本化学会第 7 年会講演）

\section{交献}

1) たとえば 電気化学便覽 昭 28 版; Landolt, Börnstein, Physikalisch-Chemische Tabellen Eg. II, 2064.

2) 牧:分析化学, 3, 311 (1954).

3）牧: 分析化学, 3, 314 (1954).

（東京農工大学農芸化学教室*）（昭和29年7月16日受理）

電気クロマトグラフによるクロム錯イオンの電荷分布分析(第1 報) 定 性 分析 (その 1)

川村亮・岡村浩・金子尙徳

Analysis of Chromium Complex Ions by Electrochromatography. I. Qualitative Analysis. (I)

Akira Kamamura, Hiroshi Okamura, and Naonori Kaneko

(Faculty of Agriculture, Tokyo University of Agriculture and Technology)

Inorganic electrochromatography heretofore has been directed on the mutual separation of inorganic ions derived from different elements. In this investigation, the above method is applied on the separation of two or more of complex ions consist of the same element, $\mathrm{Cr}$ (III), in which first, chromium oxalate complex compounds carrying the different electric charge are synthesized, next the conditions for separation by electrochromatiography are determined, then the changes of a complex salt of $\left[\mathrm{Cr}\left(\mathrm{H}_{2} \mathrm{O}\right)_{6}\right]\left[\mathrm{Cr}(\mathrm{Ox})_{3}\right]$ with aging are observed, and confirmed the formation of a compound, $\left[\mathrm{Cr}\left(\mathrm{H}_{2} \mathrm{O}\right)_{4}(\mathrm{Ox})\right]\left[\mathrm{Cr}\left(\mathrm{H}_{2} \mathrm{O}\right)_{2}(\mathrm{Ox})_{2}\right]$, in which $\mathrm{Ox}=-\mathrm{OOCCOO}-$. (Received July 16, 1954)

無機電合クロマトグラフに関する報告は Mc Donald ${ }^{1}$ ，

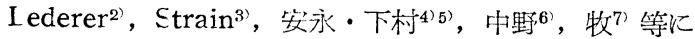
よって行われているが何れも相異る無機イオン相互間の 分離を目的としたものである。著者等は同一金属より成 る二程以上の鼠荷を翼にする錯イオンをそれぞれ区分す る目的にこの方法を応用した。霓気クロマトグラフに よる金属イオンの分瓶に関し溶媒にあらかじめ特定な酸 根等を加えて乱くと，その錯塩形成作用にもとずきカチ

* 東宗都北多摩郡府中市
オン相互間の分離能を增大する事が知られている。例兄 ば，Strain ${ }^{3}$ 等は 2 洒，多価のカチオンから 1 洒のカチ オンを分離するのにエチレンジアミンが有效である事を 述へ， 末た安永等 ${ }^{45)}$ はカチオンの移動度に刘する $\mathrm{pH}$ の影響を研究した結果，溶媒に酒石酸を加えたものが特 定の $\mathrm{pH}$ 下で各カチオンを相互に良く分離する整を認め ている. 同様な根捕から牧等8) もエチレンジアミン酒石 酸溶液を金属イオン混合溶液汇添加して彷来分㒕の難し かったアルカリ土金属， $\mathrm{Bi} ， \mathrm{~Pb}$ 等の相互分㒕が可能な 
る事を報告している・しかしこれらの研究はたとえ錯イ オンの形成を応用した場合でも何れも相晎る無機イオン 相互間の分離を目的としたもので同一元素より成る二種 以上の錯イオンの䨘荷の大小，種類を相互に区分するた めのものではない，従ってその目的の性質上，分離を志 すイオン例えばカチオンに錯根を形成し易い化合物を混 合して通鼠を行い，特定な錯化合物を合成して用いたも のではない，著者等はクロムイオンについて新たに各種 電荷の蓚酸クロム錯化合物を合成しこのるのをク口ムと 錯イオンを作り難いと認められている過塩素酸等を溶媒 として通電クロマトグラフの研究を行い, 次に示すよう な結果を得たのでここに報告する。

\section{実験}

\section{1. 使用クロム液の合成および分析}

霓荷の翼るクロム錯化合物としては次の 8 種類を使用 した。

錯化合物としての電荷が陽 3 価となる $\mathrm{Cr}$ (III) は（略号 $[\mathrm{Cr} \text { 錯 }]^{3+}$ )

$\left[\mathrm{Cr}\left(\mathrm{H}_{2} \mathrm{O}\right)_{6}\right]_{2}\left(\mathrm{SO}_{4}\right)_{3} \cdot 5 \mathrm{H}_{2} \mathrm{O},\left[\mathrm{Cr}\left(\mathrm{H}_{2} \mathrm{O}\right)_{6}\right]\left(\mathrm{ClO}_{4}\right)_{3} *$ 同じく陽 1 䣼となる $\mathrm{Cr}(\mathrm{III})$ は(略号 $[\mathrm{Cr} \text { 錯 }]^{1+}$ )

$\left[\mathrm{Cr}\left(\mathrm{H}_{2} \mathrm{O}\right)_{4}(\mathrm{Ox})\right] \mathrm{ClO}_{4}{ }^{*},\left[\mathrm{Cr}\left(\mathrm{H}_{2} \mathrm{O}\right)_{4}(\mathrm{Ox})\right]_{2} \mathrm{SO}_{4}{ }^{*}$,

$\left[\mathrm{Cr}\left(\mathrm{H}_{2} \mathrm{O}\right)_{4}(\mathrm{Ox})\right]\left(\mathrm{CH}_{3} \mathrm{COO}\right)^{*}$

同じく非解離となる $\mathrm{Cr}(\mathrm{III})$ は（略号 $\left.[\mathrm{Cr} \text { 錯 }]^{0}\right)$

$\left[\mathrm{Cr}\left(\mathrm{H}_{2} \mathrm{O}\right)_{3}(\mathrm{Ox})\left(\mathrm{CH}_{3} \mathrm{COO}\right)\right]^{*}$

同じく陰 1 価となる $\mathrm{Cr}(\mathrm{III})$ は (格号 $\left[\mathrm{Cr}\right.$ 錯 ${ }^{1-}$ )

$\left[\mathrm{Cr}\left(\mathrm{H}_{2} \mathrm{O}\right)_{2}(\mathrm{Ox})_{2}\right] \cdot \mathrm{K} \cdot 3 \mathrm{H}_{2} \mathrm{O}$

同じく㓌 3 洒となる $\mathrm{Cr}(\mathrm{III})$ は (略号 $[\mathrm{Cr} \text { 錯 }]^{3-}$ )

$\left[\mathrm{Cr}(\mathrm{Ox})_{3}\right] \mathrm{K} \cdot 3 \mathrm{H}_{2} \mathrm{O}$

(ただし Ox は蓚酸根を示す)

これらの化合物の5ち $\left[\mathrm{Cr}\left(\mathrm{H}_{2} \mathrm{O}\right)_{6}\right]_{2}\left(\mathrm{SO}_{4}\right)_{3}$ は

Weinland 等の用いた方法 ${ }^{9}$ でクロム明攀から調製し， エタノールおよびエーテルで充分に洗滌し $20^{\circ} \mathrm{C}$ 以下の 低温で乾燥した. 試料は易溶, 潮解性の紫色繗片状結晶 でバックマン分光光度計で測定した吸収極大の位置は, 405〜 410, 570 574 m $\mu$ に存在し, ベンチジン塩酸塩を 用いて硫酸根を測定したところ Cr に対する割合は次の

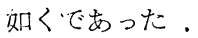

実測值 $\mathrm{Cr}_{2}\left(\mathrm{SO}_{4}\right)_{3} \cdot 17 \mathrm{H}_{2} \mathrm{O}$ としての計算值

\begin{tabular}{lcc}
\hline $\mathrm{Cr} \%$ & $\mathrm{SO}_{4} \%$ & $\mathrm{H}_{2} \mathrm{O} \%$ \\
14.46 & 42.00 & 43.53 \\
14.89 & 41.27 & 43.85 \\
\hline
\end{tabular}

405〜410 $\mathrm{m} \mu$ にお污る吸収带は $\left[\mathrm{Cr}\left(\mathrm{H}_{2} \mathrm{O}\right)_{6}\right]^{3+}$ なるイ オンに特有なものとして認められているので1011), 生じ た結晶は $\left[\mathrm{Cr}\left(\mathrm{H}_{2} \mathrm{O}\right)_{6}\right]_{2}\left(\mathrm{SO}_{4}\right)_{3} \cdot 5 \mathrm{H}_{2} \mathrm{O}$ と考えられる，また $\left[\mathrm{Cr}\left(\mathrm{H}_{2} \mathrm{O}\right)_{2}(\mathrm{Ox})_{2}\right] \mathrm{K} \cdot 3 \mathrm{H}_{2} \mathrm{O},\left[\mathrm{Cr}(\mathrm{Ox})_{3}\right] \mathrm{K} \cdot 3 \mathrm{H}_{2} \mathrm{O}$ の 2 種 類は先にクロム錯イオンのイオン交換樹脂による分析第 1 報 ${ }^{22}$ に述べた方法で調製，検定した結晶で，それぞれ のクロムに対する苳酸の比率ならびに吸収極大は次の如 きものであった。

* 号は水溶液として調製したため結晶水不明. また錯 根内の水分于の量は製造時の原料扣よび経過よりの推 定による。
$\mathrm{Ox} / \mathrm{Cr}$ 吸収極大の位置 $(\mathrm{m} \mu)$

$\mathrm{K}\left[\mathrm{Cr}\left(\mathrm{H}_{2} \mathrm{O}\right)_{2}(\mathrm{Ox})_{2}\right] 3 \mathrm{H}_{2} \mathrm{O} \quad 1.98 \quad 560 \sim 568, \quad 415$

$\mathrm{K}_{3}\left[\mathrm{Cr}(\mathrm{Ox})_{3}\right] \cdot 3 \mathrm{H}_{2} \mathrm{O} \quad 3.01 \quad 570,420$

他の化合物はこれら 3 種を原料として以下に述べる方 法で調製, 検定したが結晶にはならなかった. 従って結 晶水は不明である.

（1）錯化合物として3価陽イオンの形の $\mathrm{Cr}$ (III)化合物

(i) 6 アクオ・クロム(III)過塩素酸塩

$\left[\mathrm{Cr}\left(\mathrm{H}_{2} \mathrm{O}\right)_{6}\right]\left(\mathrm{ClO}_{4}\right)_{3}$

この化合物は先の $\left[\mathrm{Cr}\left(\mathrm{H}_{2} \mathrm{O}\right)_{6}\right]_{2}\left(\mathrm{SO}_{4}\right)_{3} \cdot 5 \mathrm{H}_{2} \mathrm{O}$ より調

製した。この経過を示すと次の如くである.

$\left[\mathrm{Cr}\left(\mathrm{H}_{2} \mathrm{O}\right)_{6}\right]_{2}\left(\mathrm{SO}_{4}\right)_{3}+6 \mathrm{HClO}_{4}+3 \mathrm{Ba}(\mathrm{OH})_{2}$

$\rightarrow 2\left[\mathrm{Cr}\left(\mathrm{H}_{2} \mathrm{O}\right)_{6}\right]\left(\mathrm{ClO}_{4}\right)_{3}+6 \mathrm{H}_{2} \mathrm{O}+3 \mathrm{BaSO}_{4} \downarrow$

すなわち正確なる既知量の紫色硫酸クロムに当量の過 塩素酸を加え, この両者の混合液に計算量のバリタ水を 徐々に加えて正磪に硫酸根を硫酸バリウムの沈澱として 除去した．得られた液は紫青色の二色性があり $0.1 \%$ $\left(\mathrm{Cr}_{2} \mathrm{O}_{3}\right)$ 水溶液で $\mathrm{pH} 2.92$ (硝子電極にて測定), ベック マン分光光度計による吸取極大の位置は 405〜 412, 571 $\sim 576 \mathrm{~m} \mu$ の 2 ケ所に存在し, 先の $\left[\mathrm{Cr}\left(\mathrm{H}_{2} \mathrm{O}\right)_{6}\right]^{3+}$ に特 有な吸収带ともほぼ一致している。なおこの液はバンチ ジン塩酸塩による硫酸根の沈澱も, 逆に硫酸根添加によ る $\mathrm{BaSO}_{4}$ の沈澱も, 認められずかつ加熱を行っても冷 後の色調, $\mathrm{pH}$ 共に不变でクロムはすべて $\left[\mathrm{Cr}\left(\mathrm{H}_{2} \mathrm{O}\right)_{6}\right]$ $\left(\mathrm{ClO}_{4}\right)_{3}$ なる型で存在する事を認めた。たお得られた液 はバリタ水の濃度の関係上 $0.5 \%\left(\mathrm{Cr}_{2} \mathrm{O}_{3}\right)$ 内外の稀薄な ものであったので涷結濃縮を反復して 6〜7\%の濃度と した.

（2）錯化合物として1価陽イオンの形の $\mathrm{Cr}$ (III)化合物。 核内にアムモニアやエチレンジアミン等の中性部分を 有する 1 価陽錯イオンの形の $\mathrm{Cr}$ (III) 化合物は現在迄に 得られているが，1オキザラト・4アクオ・クロム(III) 化合物は未だに溶液中のその存在が証明されているだけ である ${ }^{13)}$. M. Abenstern は各種のク口ム原料から〔Cr $\left.\left(\mathrm{H}_{2} \mathrm{O}\right)_{4}(\mathrm{Ox})\right] \mathrm{X} な る$ 化合物(ただしXは酸根を示す)を作 っているが ${ }^{13)}$ ，この際は他の錯結合し易い中性塩を共存 する事も多く，またその単離結晶化も成功しなかった。

著者等は次に述べるイオン交換樹脂を使用した新しい 経過で 2〜3 の酸の $\left[\mathrm{Cr}\left(\mathrm{H}_{2} \mathrm{O}\right)_{4}(\mathrm{Ox})\right] \mathrm{X}$ なる形の塩を 合成した. このものは検定の結果殆んど 1 洒の錯陽一オ ンであると認められたがやはりその結晶化は成功せず， 得られたるのは潮解性を有する無定形固体であった。

(i) オキザラト・4アクオ・クロム(III)過塩素酸 塩 $\left[\mathrm{Cr}\left(\mathrm{H}_{2} \mathrm{O}\right)_{4}(\mathrm{Cx})\right] \mathrm{ClO}_{4}$

この化合物の調製経過を示すと次の吅くである。

$$
\begin{aligned}
& {\left[\mathrm{Cr}\left(\mathrm{H}_{2} \mathrm{O}\right)_{2}(\mathrm{Ox})_{2}\right] \mathrm{K} \overrightarrow{\mathrm{H} \text { 形IR-120 }}} \\
& {\left[\mathrm{Cr}\left(\mathrm{H}_{2} \mathrm{O}\right)_{2}(\mathrm{Ox})_{2}\right] \mathrm{H}} \\
& {\left[\mathrm{Cr}\left(\mathrm{H}_{2} \mathrm{O}\right)_{6}\right]_{2}\left(\mathrm{SO}_{4}\right)_{3}+2\left[\mathrm{Cr}\left(\mathrm{H}_{2} \mathrm{O}\right)_{2}(\mathrm{Ox})_{2}\right] \mathrm{H}} \\
& +4 \mathrm{HClO}_{4}+3 \mathrm{Ba}(\mathrm{OH})_{2} \rightarrow 2\left[\mathrm{Cr}\left(\mathrm{H}_{2} \mathrm{O}\right)_{6}\right]\left[\mathrm{Cr}\left(\mathrm{H}_{2} \mathrm{O}\right)_{2}\right. \\
& \left.(\mathrm{Ox})_{2}\right]\left(\mathrm{ClO}_{4}\right)_{2}+6 \mathrm{H}_{2} \mathrm{O}+3 \mathrm{BaSO}_{4} \quad \cdots \cdots \cdots \cdots \cdots \cdot 2 \\
& {\left[\mathrm{Cr}\left(\mathrm{H}_{2} \mathrm{O}\right)_{6}\right]\left[\mathrm{Cr}\left(\mathrm{H}_{2} \mathrm{O}\right)_{2}(\mathrm{Ox})_{2}\right]\left(\mathrm{ClO}_{4}\right)_{2} \overrightarrow{\text { 老化 }}} \\
& 2\left[\mathrm{Cr}\left(\mathrm{H}_{2} \mathrm{O}\right)_{4}(\mathrm{Ox})\right] \mathrm{ClO}_{4} \ldots \ldots \ldots \ldots \ldots \ldots \ldots \ldots \ldots . \cdots \cdots
\end{aligned}
$$


すなわち $\left[\mathrm{Cr}\left(\mathrm{H}_{2} \mathrm{O}\right)_{2}(\mathrm{Ox})_{2}\right] \mathrm{K}$ の $5.0 \%\left(\mathrm{Cr}_{2} \mathrm{O}_{3}\right)$ 程度 の水溶液を Amberlite IR-120 のH型のものを通過しK をHで置換し，得られた酸のクロム濃度を定量し，この ものに 2 式に従って硫酸クロムおよび過塩素酸を加穴, 更に計算量のバリタ水を徐々に添加して硫酸根を完全に 除去した. 得られた液は前同様にして遄剩の硫酸根や: リウムイオンの存在しない事を確かめ, 次いで 6 カ月間 $30^{\circ} \mathrm{C}$ にて 3 式泪当する老化を行った. この間分析の 目的で約 $0.1 \%\left(\mathrm{Cr}_{2} \mathrm{O}_{3}\right)$ 液 $40 \mathrm{cc}\left(41.6 \mathrm{mg} \mathrm{Cr} \mathrm{C}_{2} \mathrm{O}_{3}\right)$ を 2 , $7 ， 14 ， 120 ， 180$ 日目においてそれぞれ陰イオン交換体 Amberlite IR-4B-醋酸塩 $5.0 \mathrm{~g}$ を充したカラム（内径 $8.0 \mathrm{~mm}$, 長さ $150.0 \mathrm{~mm}$ ) 飞 $40^{\circ} \mathrm{C}$ とて通過し $\left.{ }^{12)} 14\right)$, 漏 出するクロム量拉よびその際の $\mathrm{C}_{2} \mathrm{O}_{4} / \mathrm{Cr}$ を測定し第 1 表の如き結果を得た.

第 1 表 時間飞伴弓“ $\left[\mathrm{Cr}\left(\mathrm{H}_{2} \mathrm{O}\right)_{6}\right]\left[\mathrm{Cr}\left(\mathrm{H}_{2} \mathrm{O}\right)_{2}(\mathrm{Ox})_{2}\right]\left(\mathrm{ClO}_{4}\right)_{2}$ の変化

\begin{tabular}{|c|c|c|c|}
\hline & 原 & 液 & 2 日後 \\
\hline $\begin{array}{l}\text { 錯イオンとして陽 } \\
\text { 電荷を持っ } \mathrm{Cr} \text { (III)量 } \\
\text { 上 記 錯 イ オ } \\
\text { 中 の } \mathrm{C}_{2} \mathrm{O}_{4} / \mathrm{Cr} \\
\end{array}$ & 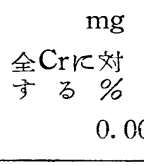 & $\begin{array}{l}21.07 \\
50.66 \\
\end{array}$ & $\begin{array}{r}22.67 \\
54.50 \\
0.41\end{array}$ \\
\hline 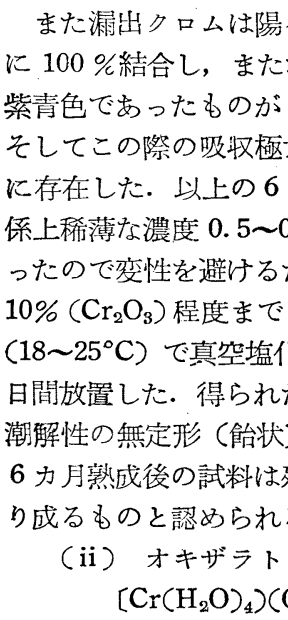 & 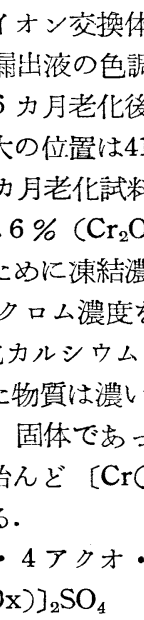 & $\begin{array}{l}\text { 青紅色の } \\
\text { た. 以」 } \\
\left.\mathrm{H}_{2} \mathrm{O}\right)_{4}(\mathrm{O}\end{array}$ & $\begin{array}{l}\text { タ一中 } \\
\text { 二色性 } \\
\text { の経邉 } \\
\text { x) JClC }\end{array}$ \\
\hline
\end{tabular}

この化合物は(i)によって合成, 検定した $\left[\mathrm{Cr}\left(\mathrm{H}_{2} \mathrm{O}\right)_{4}\right.$ $(\mathrm{Ox})] \mathrm{ClO}_{4} 5 \%\left(\mathrm{Cr}_{2} \mathrm{O}_{3}\right) 10 \mathrm{cc}$ を陰イオン交換体 Amberlite IR A-410 $20 \mathrm{~g}$ をあらかじめ硫酸にて飽和し充分に水洗 したものに通過し, 過塩素酸根を硫酸根に变光た，得ら れた液のクロムは陽イオン交換体 IR-120 亿 100\% 結合 し，その色調並びに吸取極大は (i)の場合と全く同じで あった。 またクロムに対する落酸根拈よび核外硫酸根の 割合 (それぞれセリウム法およびベンチジン塩酸塩法で 測定) は次の如くで, 試料は全部 $\left[\mathrm{Cr}\left(\mathrm{H}_{2} \mathrm{O}\right)_{4}(\mathrm{Ox})\right]_{2} \mathrm{SO}_{4}$ に変った事を認めた。

$$
\mathrm{Cr}: \mathrm{OX}: \mathrm{SO}_{4}=1.00: 1.02: 0.49
$$

（iii）オキザラト・4アクオ・クロム（III）醋酸㙁 $\left[\mathrm{Cr}\left(\mathrm{H}_{2} \mathrm{O}\right)_{4}(\mathrm{Ox})\right]\left(\mathrm{CH}_{3} \mathrm{COO}\right)$

この化合物も前同梯 (i)によって合成した $\left[\mathrm{Cr}\left(\mathrm{H}_{2} \mathrm{O}\right)_{4}\right.$ $(\mathrm{Ox}) \mathrm{ClO}_{4} 5 \%\left(\mathrm{Cr}_{2} \mathrm{O}_{3}\right) 10 \mathrm{cc}$ を IRA-410 $20 \mathrm{~g}$ をあらか じめ酥酸にて饱和水洗したものに通過し, 過塩素酸根を 醋酸根に置換した。得られた液のクロムは陽イオン交換
体 IR-120 亿 $100 \%$ 結合し,その色調, 吸収極大ともに(i) (ii) と変りなく, クロムに対する苳酸, 醋酸根の制合は 次の如くで試料はすべて $\left.\left.\left[\mathrm{Cr}\left(\mathrm{H}_{2} \mathrm{O}\right)_{4}\right) \mathrm{Ox}\right)\right]\left(\mathrm{CH}_{3} \mathrm{COO}\right)$ •なる形で存在する專を認めた。

$\mathrm{Cr}: \mathrm{Ox}: \mathrm{CH}_{3} \mathrm{COO}=1.00: 1.02: 0.96$

末田100炕よれ゙クロム核内に酸根が入れば一般に最大 四収は長波長の方に移動し $\left[\mathrm{Cr}\left(\mathrm{H}_{2} \mathrm{O}\right)_{4} \mathrm{Cl}_{2}\right]+$ なる 1 価の 錯陽イオンの吸取極大の位置は $443 \mathrm{~m} \mu$ であるとい5か ら (i) (ii) (iii) における 416 420 $\mathrm{m} \mu$ の吸取は [ $\mathrm{Cr}$ $\left.\left(\mathrm{H}_{2} \mathrm{O}\right)_{4}(\mathrm{Ox})\right]^{+}$なる錯イオン特有なるのと思われる.

（3）錯化合物として非解離形の $\mathrm{Cr}$ (III) 化合物

(i) オキザラト・アセタト・3アクオ・クロム (III) $\left[\mathrm{Cr}\left(\mathrm{H}_{2} \mathrm{O}\right)_{3}(\mathrm{Ox})\left(\mathrm{CH}_{3} \mathrm{COO}\right)\right]$

この化合物は(iii)によって合成した $\left[\mathrm{Cr}\left(\mathrm{H}_{2} \mathrm{O}\right)_{4}(\mathrm{Ox})\right]$ $\left(\mathrm{CH}_{3} \mathrm{COO}\right)$ を 60 分間加

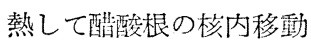
を促進すると同時に濃㴼 を行った。この变化の経 過を示して見ると次の如 くである.

$\left[\mathrm{Cr}\left(\mathrm{H}_{2} \mathrm{O}\right)_{4}(\mathrm{Ox})\right]$

$\left(\mathrm{CH}_{3} \mathrm{COO}\right)$ 加熱 $\left[\mathrm{Cr}\left(\mathrm{H}_{2} \mathrm{O}\right)_{3}(\mathrm{Ox})\left(\mathrm{CH}_{3} \mathrm{COO}\right)\right]$

冷却後アニオン交換体 IRA-410 の $\mathrm{RClO}_{4}$ 形小よびカ チオン交換体 IR-120 のHR 形を通過して未变化の[Cr $\left.\left(\mathrm{H}_{2} \mathrm{O}\right)_{4}(\mathrm{Ox})\right]^{+}$および $\mathrm{CH}_{3} \mathrm{COO}^{-}$を除去した. 得られ た液は 1 週間放置しても陰陽何れのイオン交換樹脂にも 結合せず，全部が非解離形のクロムなる等を認めた。

\section{2. 実験方法}

東洋濾紙 No. 50 を巾 $5 \mathrm{~mm}$, 長さ $380 \mathrm{~mm}$ の短冊形 に切り中央部を最高として山形に折り, 密閉ガラス鐘中 に懸垂し同端を $10 \mathrm{~mm}$ ずつ展開溶媒を充した槽の中 に浸清し, 後滤紙の全体を溶媒でうる扎した. 実験汇当 っては溶媒槽中に插入した炭素霞極を通じ一定雷压で 5 分間通電を行い, 展開剤の安定した後あらかじ印を附 した滤紙中央 (原点) に一定濃度の試料をミクロ・ピペ ットを以て添加しその後更に 1.0 時間通麗を行い試料の 移動状況を観察した。な通雪のための直流発生装置は 出力電圧 $0 \sim 1000 \mathrm{~V}$, 同電流 $0 \sim 20 \mathrm{~mA}$ のもの (東洋濾 紅霓気泳動装置匹号) を使用した, 試料の添加量は一定 濃度のクロム液が乾燥港紙上で常に $5.0 \mathrm{~mm}$ のスポット となるが如き量をとり，通電後は㵂紙を風乾して $5.0 \%$ $\mathrm{NaOH}$, 次いで $5.0 \% \mathrm{H}_{2} \mathrm{O}_{2}$ を噴霧してクロムの酸化を 行い, 更に乾燥後醋酸鉛を貲霧して照紙上に $\mathrm{PbCrO}_{4}$ の 黃色沈測を生成せしめて呈色を行った。

\section{3. 純粋クロム化合物を用いた通電條件決定}

(1) 展開剤の種類

展開剤としては最初に次の 5 種類を使用した。

(1)醋酸，醋酸ソーダ䌊衝液 $(\mathrm{pH} 3.6)$

(2) $N / 30 \mathrm{HClO}_{4}$ 水溶液

(3)ブタノール飽和 $N / 30 \mathrm{HClO}_{4}$ 水溶液

(4) $N / 30 \mathrm{NaClO}_{4}$ 水溶液

(5) $N / 30 \mathrm{HClO}_{4}$ 、ブタノール, エタノール(2:1:1) 湜液 


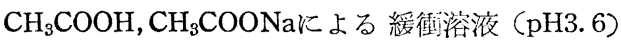

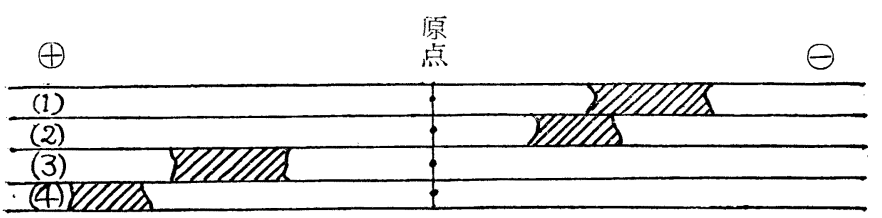

$N / 30-\mathrm{HClO}_{4}$

( $)$
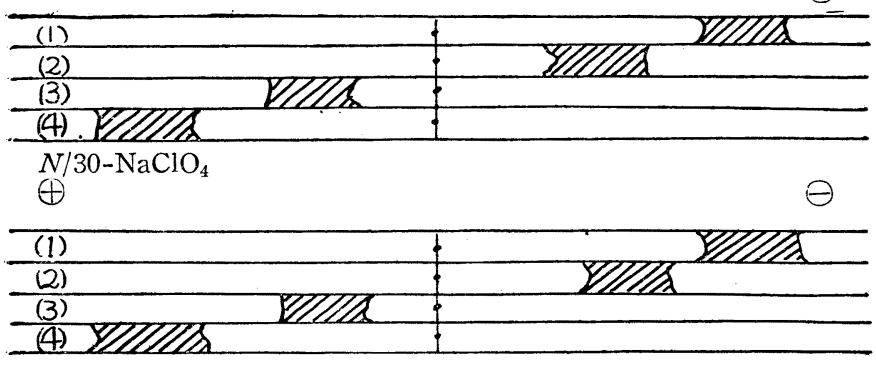

ブタノール飽和 $\mathrm{N} / 30-\mathrm{HClO}_{4}$

$\oplus$

$\Theta$

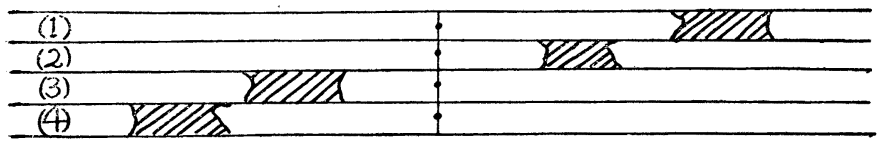

$N / 30-\mathrm{HClO}_{4}$, ブタフール,エタフール洹液 $(2: 1: 1)$

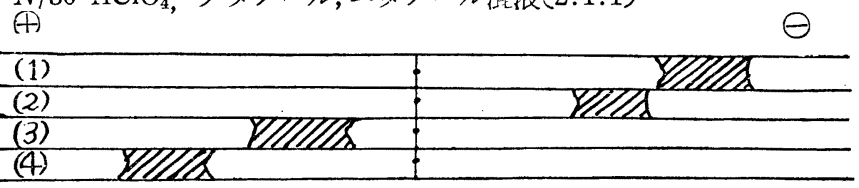
(1) $\left[\mathrm{Cr}\left(\mathrm{H}_{2} \mathrm{O}_{6}\right)\right]\left(\mathrm{ClO}_{4}\right)_{3}$
(2) $\left[\mathrm{Cr}\left(\mathrm{H}_{2} \mathrm{O}\right)_{4}(\mathrm{Ox})\right] \mathrm{ClO}_{4}$
(3) $\left[\mathrm{Cr}\left(\mathrm{H}_{2} \mathrm{O}\right)_{2}(\mathrm{Ox})_{2}\right] \mathrm{K}$
(4) $\left[\mathrm{Cr}\left(\mathrm{Ox}_{3}\right)\right] \mathrm{K}_{3}$

第 1 図 展開溶媒を変えた際の蓚酸クロムの通電移動 (200V，1 時間)

$$
\left[\mathrm{Cr}\left(\mathrm{H}_{2} \mathrm{O}\right)_{6}\right]\left(\mathrm{ClO}_{4}\right)_{3}
$$

$\oplus$

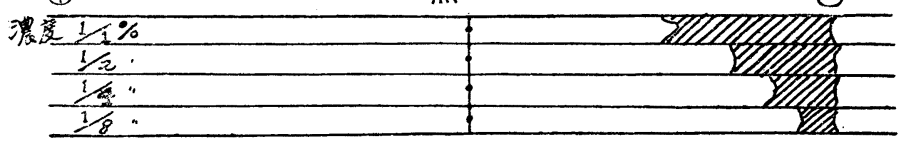

$\left[\mathrm{Cr}\left(\mathrm{H}_{2} \mathrm{O}\right)_{4}(\mathrm{Ox})\right] \mathrm{ClO}_{4}$

$\oplus$

$\ominus$

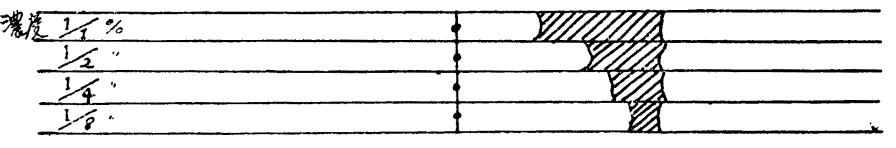

$\left[\mathrm{Cr}\left(\mathrm{H}_{2} \mathrm{O}\right)_{2}(\mathrm{Ox})_{2}\right] \mathrm{K}$

$\oplus$

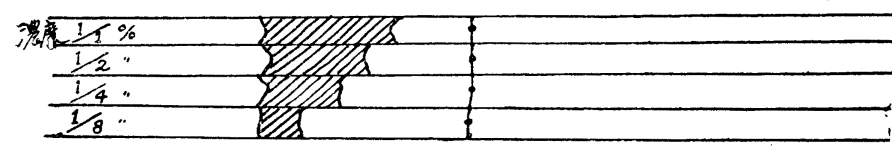

$\left[\mathrm{Cr}(\mathrm{Ox})_{3}\right] \mathrm{K}_{3}$

$$
\oplus
$$

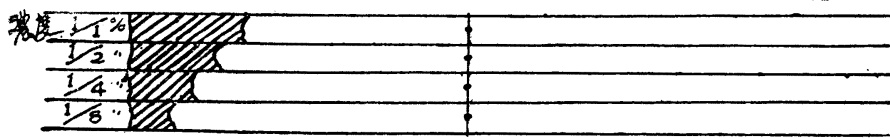

第 2 圀 濃度变化に伴 5 苳酸クロムの通電移動 (200V, 1 時間)
以上の展開溶媒と先の $\left[\mathrm{Cr}\left(\mathrm{H}_{2} \mathrm{O}\right)_{6}\right]$ $\left(\left(\mathrm{ClO}_{4}\right)_{3},\left[\mathrm{Cr}\left(\mathrm{H}_{2} \mathrm{O}\right)_{4}(\mathrm{Ox})\right] \mathrm{ClO}_{4},[\mathrm{Cr}\right.$ $\left.\left(\mathrm{H}_{2} \mathrm{O}\right)_{2}(\mathrm{Ox})_{2}\right] \mathrm{K},\left[\mathrm{Cr}(\mathrm{Ox})_{3}\right] \mathrm{K}_{3}$ の 4 種 類の試料とを用いて濃度 $0.5 \%\left(\mathrm{Cr}_{2} \mathrm{O}_{3}\right)$ $200 \mathrm{~V}$ 定麗压, 1.0 時間, 上法に上る通 雪を行ったここの場合 1 回の実験，すな わち 1 種類の痕開剤について 8 種類の試 料を同時に平行に㲘垂した. 溶媒として 特に過塩素酸を多く用いたのは，このむ のがクロムと最も錯イオンを作り難い事 を考虑したもので, また展菛羭の濃度と して N/: 0 を選んだのは通電量の関係 (2〜10 mA) からである. 実験中のガラ ス鐘中の温度は $18^{\circ} \sim 21^{\circ} \mathrm{C}$ て滤紙上に は抵抗による鼬度上抙が兰然存在するが 溶媒の蒸発が同時に行われるので余り大 きな影響はない，ただ時間の経過と共に 滤紙下端より溶媒の上昇が盛んになり， 通電時間を延長しても余り大きなイオン の動きが得られない欠点があり,この点

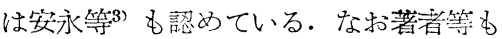
Consden ${ }^{15}$ が用いたクロールベンゾール 中に展開溶媒でうるおした濾紙を浸涽す る方法, また 2 枚のガラス板の閽、滤紙 をはさんで泠却する方法などを試みた が们れも特に良好な結果は得られなかっ た.

上記操作によって得られたスポットの 移動を図示して見ると第 1 区の如くであ る.

すなわち溶媒 1 以外は何れの場合も殆 んど差買なく麗荷の異る 4 種の錯イオン を分離展開し得る事を認めた。

(2) 試料の量的関係

展開溶媒として $\mathrm{N} / 30-\mathrm{HClO}_{4}$ を用い， 試料としては(1)に使用した 4 種のクロム 化合物の $1.0 \%\left(\mathrm{Cr}_{2} \mathrm{O}_{3}\right)$ のものをそれぞ れ $1 / 1,1 / 2,1 / 4,1 / 8$ の濃度に稀勫し 同種稀粕試料について同時に $200 \mathrm{~V}, 1.0$ 時間の条件で通電を行い第 2 脑の如き結 果を得た。

すなわち試料の量が変化してもその前 端はほぼ一致する。しかしクロム量が増 加して来るとスポットが長くなり個及の 分離が不可能となる．また量的に少くな ければスポットは小さくなるが呈色は弱 くなる. 以上の結果から一般に $1 / 4 \%$ 程度のものか淀性的に分離呈色共に良好 なる事を認めた。

\section{(3) 電圧, 時間の影響}

䉓圧, 時間を変化した際のクロムの移 動状況を検するために先の 4 種の化合物 の他, 更汇試料として $\left[\mathrm{Cr}\left(\mathrm{H}_{2} \mathrm{O}\right)_{6}\right]_{2}\left(\mathrm{SO}_{4}\right)_{3}$, 
$300 \mathrm{~V} 30$ 分

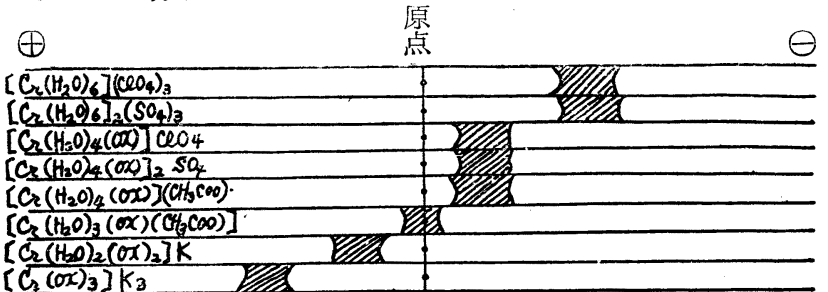

$500 \mathrm{~V} 60$ 分

$\oplus$

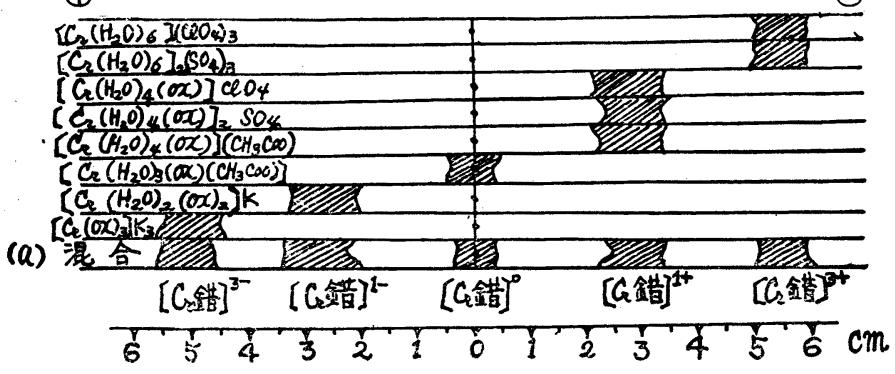

第 3 図 霓压, 時間の变化に伴 5 クム錯イオンの移動
$\left[\mathrm{Cr}\left(\mathrm{H}_{2} \mathrm{O}\right)_{4}(\mathrm{Ox})\right]\left[\mathrm{Cr}\left(\mathrm{H}_{2} \mathrm{O}\right)_{2}(\mathrm{Ox})_{2}\right] な$ いわゆる配位暴性体を生成する事を推定 した、本実験例においてはこの現象を上

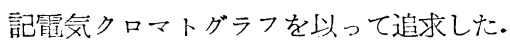
すなわち $\left[\mathrm{Cr}(\mathrm{Ox})_{3}\right] \mathrm{K}_{3}$ 水溶液を陽イオ ン交換体 Amberlite IR 120-H を通じて $\left[\mathrm{Cr}(\mathrm{Ox})_{3}\right]_{\mathrm{H}_{3}}$ となし, このものに当量 の $\left[\mathrm{Cr}\left(\mathrm{H}_{2} \mathrm{O}\right)_{6}\right]_{2}\left(\mathrm{SO}_{4}\right)_{3}$ を加光, 次いで $\mathrm{Ba}(\mathrm{OH})_{2}$ 水溶液で正確に $\mathrm{SO}_{4}$ を除去し, その老化 $\left(15^{\circ} \mathrm{C}\right)$ に伴らスポットの变化 を所定の条件で観察し第 4 図の如き結果 を得た。

すなわち試料の合成直後には $\left[\mathrm{Cr}_{\text {錯 }}\right]^{3+}$ と [Cr錯 $]^{3-}$ の部分に見られたスポット が 1 週後には [Cr錯 $]^{1+}$ と $[\mathrm{Cr} \text { 錯 }]^{1-}$ の大 ポットを加え, 更に 1 ケ月後には完全に [Cr踖] ${ }^{1+}$ と[Cr錯 $]^{1-}$ のみになった。従 ってこの実験においても明らかに

$\left[\mathrm{Cr}\left(\mathrm{H}_{2} \mathrm{O}\right)_{6}\right]\left[\mathrm{Cr}(\mathrm{Ox})_{3}\right]$ 老化 $[\mathrm{Cr}$ $\left(\mathrm{H}_{2} \mathrm{O}_{4}(\mathrm{Ox})\right]\left[\mathrm{Cr}\left(\mathrm{H}_{2} \mathrm{O}\right)(\mathrm{Ox})_{2}\right]$
$\left[\mathrm{Cr}\left(\mathrm{H}_{2} \mathrm{O}\right)_{4}(\mathrm{Cx})\right]_{2} \mathrm{SO}_{4}, \quad\left[\mathrm{Cr}\left(\mathrm{H}_{2} \mathrm{O}\right)_{4}(\mathrm{Ox})\right]\left(\mathrm{CH}_{3} \mathrm{COO}\right)$ $\left[\mathrm{Cr}\left(\mathrm{H}_{2} \mathrm{O}\right)_{3}(\mathrm{Ox})\left(\mathrm{CH}_{3} \mathrm{COO}\right)\right]$ を加光，濃度 $1 / 4 \%\left(\mathrm{Cr}_{2} \mathrm{O}_{3}\right)$ 展開剤 $N / 30 \mathrm{HClO}_{4}, 300 \mathrm{~V}, 30$ 分拈よび $500 \mathrm{~V}, 1$ 時間 の条件で実験を行ったところ第 3 図の如き結果を得た。

次に約 $1.2 \%\left(\mathrm{Cr}_{2} \mathrm{O}_{3}\right)$ の $\left[\mathrm{Cr}\left(\mathrm{H}_{2} \mathrm{O}\right)_{6}\right]_{2}\left(\mathrm{SO}_{4}\right)_{3},[\mathrm{Cr}$ $\left.\left(\mathrm{H}_{2} \mathrm{O}\right)_{4}(\mathrm{Ox})\right]_{2} \mathrm{SO}_{4},\left[\mathrm{Cr}\left(\mathrm{H}_{2} \mathrm{O}\right)_{3}(\mathrm{Ox})\left(\mathrm{CH}_{3} \mathrm{COO}\right)\right],[\mathrm{Cr}$ $\left.\left(\mathrm{H}_{2} \mathrm{O}\right)_{2}(\mathrm{Cx})_{2}\right] \mathrm{K},\left[\mathrm{Cr}(\mathrm{Ox})_{3}\right] \mathrm{K}_{3}$ ，なる 5 程類の試料を等 量ずっ混合して $500 \mathrm{~V}, 1$ 時間の条件で通霞を行ったと ころ，同図 (a)の如きスポットを得た。この場合 2 時間, 3 時間と通鼠時間を延長してもスポットの位置, 長さ共 に砝ど 1 時間の場合と差がなかった。すなわら苳酸ク口 ム錯イオンの混合物はこの程度の通電条件では破壊を起 す事もまた互いに反応する事もなく，単独の場合と全く 同様に相互を分離する事ができる. 以上の実験結果から クロム錯イオンの分㒕には霓気クロマトグラフを応用す る事ができ，かつ次の通䨘条件が適当と認められる.

溶媒 $N / 30 \mathrm{HClO}_{4}$; 鼠圧 $500 \mathrm{~V}$ (䨟流は 2.0 10.0mA); 通雷時間 1.0 晊間; 滤紙巾 $5 \mathrm{~mm}$, 長さ $380 \mathrm{~mm} 8$ 枚保度 同時毇垂; 試料 $0.25 \sim 1.20 \%\left(\mathrm{Cr}_{2} \mathrm{O}_{3}\right)$ 诓度のものを $5 \mathrm{~mm}$ スポット量使用（通霓㡺開後の1つのスポットの濃度が $1 / 4 \% \mathrm{Cr}_{2} \mathrm{O}_{3}$ 程度方最適)

\section{4. 実 験 例}

著著等は先にク口ム䩼の研究第 2 報16) において $\left.\left(\mathrm{H}_{2} \mathrm{O}\right)_{6}\right]_{2}\left(\mathrm{SO}_{4}\right)_{3}$ と $\mathrm{K}_{3}\left[\mathrm{Cr}(\mathrm{Ox})_{3}\right]$ から $\left[\mathrm{Cr}\left(\mathrm{H}_{2} \mathrm{O}\right)_{6}\right][\mathrm{Cr}$ $(\mathrm{Ox})_{3}$ 】なる化合物を合成し，このものを熟成した場合
$\oplus \quad\left[\mathrm{Cr}_{\text {錯 }}\right]^{3-}$
$[\mathrm{Cr} \text { 錯 }]^{1-}$
$\left[\mathrm{Cr}_{\text {錯 }}\right]^{0}$
$\left[\mathrm{Cr}_{\text {錯 }}\right]^{3+}$

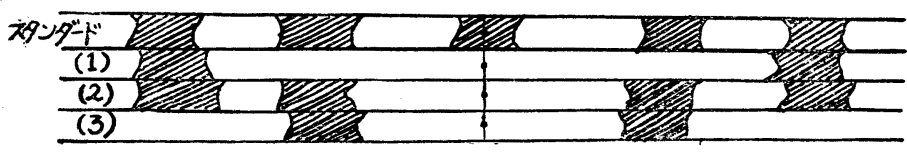

原点
(1) 㨁
後
(2) 一遇閶後
(3) 一力月後

第 4 园 $\left[\mathrm{Cr}\left(\mathrm{H}_{2} \mathrm{O}\right)_{6}\right]\left[\mathrm{Cr}(\mathrm{Ox})_{3}\right]$ の老化に伴う電荷の变化
なる変化の起る事を推定する等ができた。

要 約

同一金属より成る 2 䅜以上の鼠荷を異にする錯イオン のそれぞれを区分する目的で雪気クロマトグラフを使用 した.この場合，䨮荷の判明した各種の苳酸クロム錯化 合物を合成し，このるのの通鼠時の流紙上の变化移動を 観察した. その結果各ク口ム錯イオンは分解寸る事なく、 陰陽両錯イオン其に個及の臂荷の大いさに徉って順次遠 いところにスポットとなって嗝開する事を認め, かつこ の分離に適当なる実験条件を定めた，次いでこの条件に 従って $\left[\mathrm{Cr}\left(\mathrm{H}_{2} \mathrm{O}\right)_{6}\right]\left[\mathrm{Cr}(\mathrm{Ox})_{3}\right]$ なる錯塩の老化に伴5变 化を観察し $\left[\mathrm{Cr}\left(\mathrm{H}_{2} \mathrm{O}\right)_{4}(\mathrm{Ox})\right]\left[\mathrm{Cr}\left(\mathrm{H}_{2} \mathrm{O}\right)_{2}(\mathrm{Ox})_{2}\right]$ なるイ オンを生ずる事を認めた。

本研究に当り終始御指䆃を顶いた京都大学農学部井上 吉之先生に深謝する.

交献

1) H. J. McDonald, M. C. Urbain, M. B. Williamson : Science, 112, 227 (1950).

2) M. Lederer : Nature 167, 864 (1951) ; Australian J. Sci. 13, 114 (1951).

3) H. Strain, J. C. Sullivan : Anal. Chem., 23, 816 (1951).

4) 安永峻五, 下村修: 薬誌, 74, 1, 62 (1954).

5) II II:薬誌, 74, 1, 66 (1954).

6) 仲野倚一：日化，73，912 (1952).
$\left[\mathrm{Cr}_{\text {錯 }}\right]^{3+} \ominus$

7) 牧正交: 分化, 3, 1, 39 (1954).
8）" 稲荷田万里子：日本化学 会第 7 年会講演 (1954.4).

9) R. F. Weinland, R. Krebs : Z. Anorg. Chem. 49, 165 (1906).

10）末田秀夫 : 東工大学報, 6, 333 (1937).

11) E. L. King, E. B. Dismukes : 
J. Am. Chem. Soc., 74, 1674 (1952).

12) 井上, 川村, 和田, 岡村: 分化, 2, 21 (1953).

13) M. Abendstern: H. der Gerbereichemie und Lederfabrikation, II Band, 2 Teil, 158 (1939).
14) 井上, 川村, 和田, 岡村 : 分化, 2, 121 (1953)

15) R. Consden, W. M. Stanier : Nature, 170, 1069 (1952).

16) 川村, 和田, 山口: 農化, 26, 650 (1952)。

(東京農工大学農芸化学敉室 ${ }^{*}$ ) (昭和 29 年 7 月 16 日受理)

\title{
電気クロマトグラフによるクロム錯イオンの電荷分布分析(第2 3報)
}

\author{
川村亮・岡 村浩
}

\section{Analysis of Chromium Complex Ions by Electrochromatography. II. III.}

Akira Kawamura and Hiroshi OKamura

(Faculty of Agriculture, Tokyo University of Agriculture and Technology)

\section{Qualitative Analysis. (II)}

The analytical method in order to estimate the distribution of electrical charges of chromium complex ions by electrochromatography as established in the preceeding report on chromium oxalate, could be applied on chromium perchlorate and chromium sulfate. This method was also applied on a solution of chromium perchlorate treated with various neutral salts and on a solution of dichromates reduced with glucose, methanol, glycerin, ethylene glycol and sodium thiosulfate, etc. and found that charge distribution of the chromium complexes were much different depending on the kind of neutral salts added, and the kind of reducing agent used; reduced solution, prepared by using glucose and methanol gave a special ion, corresponding to $[\mathrm{Cr}(\operatorname{complex})]^{+}$, which was not found in those by using other reducing agents.

\section{Quantitative Analysis}

As a method of analysis of chromium complex ion, an attempt has been made on the quantitative estimation by use of electrochromatography. Ions after electromigration are dissolved and estimated by usual method. Previous to the experiments, the condition to the electrical migration are established by pure chromium compexes, then the studies are carried out on alkali treated or heated, pure, positive $\mathrm{Cr}$ (III) complex ions and various $\mathrm{Cr}$ (III) solutions from dichromate, and the distributions of the charge of chromium complexes in these solutions are analyzed. The result showed that (1) the formation of non-positively charged chromium complex ions from positivly charged chromium was not possible by a mere addition of alkali and this was possible only after heating; (2) non-positively charged chromium was not formed by heating of chromium perchlorate; (3) solution of a pure, positively charged chromium complex compounds did not form nondissociated chrome in the solution by heating, but the reduced solution from dichromate containd always some non dissociated chromes.

(Received July 16, 1954)

\section{第 2 報 定 性 分 析（その 2)}

\begin{abstract}
著者等は先に雷荷の罢る葰酸クロム錯イオンの霞気ク ロマトグラフによる分離について報告しだ．本報告は この分析方法がクロム核内の酸根の種類を変えた場合, またアルカリ添州にってある程度オール化を起した場 合等にも適用し得るや否やを検討し，以下述べる様な結 果を得たのでここ泮告する。

実験
\end{abstract}

試料としては第 1 報”に合成した次の 7 程類のクロム 化合物を使用した。

$\left[\mathrm{Cr}\left(\mathrm{H}_{2} \mathrm{O}\right)_{6}\right]_{2}\left(\mathrm{SO}_{4}\right)_{3}, \quad\left[\mathrm{Cr}\left(\mathrm{H}_{2} \mathrm{O}\right)_{6}\right]\left(\mathrm{ClO}_{4}\right)_{3}, \quad\left[\mathrm{Cr}\left(\mathrm{H}_{2} \mathrm{O}\right)_{4}\right.$ $(\mathrm{Ox})]_{2} \mathrm{SO}_{4},\left[\mathrm{Cr}\left(\mathrm{H}_{2} \mathrm{O}\right)_{4}(\mathrm{Cx})\right] \mathrm{ClO}_{4},\left[\mathrm{Cr}\left(\mathrm{H}_{2} \mathrm{O}\right)_{3}(\mathrm{Ox})\right.$

$\left.\left(\mathrm{CH}_{3} \mathrm{COO}\right)\right],\left[\mathrm{Cr}\left(\mathrm{H}_{2} \mathrm{O}\right)_{2}(\mathrm{Ox})_{2}\right] \mathrm{K},\left[\mathrm{Cr}(\mathrm{Ox})_{3}\right] \mathrm{K}_{3}$ な技实験方法及び条件はすべて前報に準じた。

* 倲京都北多嚤郡府中市

\section{1. アルカリ添加の影響}

3 洒のクロム液は加熱やアルカリ添加によって膠質化 を伴うのが普通である. 従って笔気クロマトグラフを一 般クロム液の霞荷分析に応用するためにはこの問題の検 討が必要と考兄られる.ク口ム錯イオンのうち陰麗荷の ものは余り明確な膠質化が見られない. 従ってアルカリ 添加によって膠質化するのは主に陽電荷のクロムである。 著者等は陽電荷クロム錯イオンとして $\left[\mathrm{Cr}\left(\mathrm{H}_{2} \mathrm{O}\right)_{6}\right]_{2}$ $\left(\mathrm{SO}_{4}\right)_{3},\left[\mathrm{Cr}\left(\mathrm{H}_{2} \mathrm{O}\right)_{6}\right]\left(\mathrm{ClO}_{4}\right)_{3},\left[\mathrm{Cr}\left(\mathrm{H}_{2} \mathrm{O}\right)_{4}(\mathrm{Ox})\right]_{2} \mathrm{SO}_{4},[\mathrm{Cr}$ $\left(\mathrm{H}_{2} \mathrm{O}\right)_{4}(\mathrm{Ox}) \mathrm{ClO}_{4}$ の 4 種を選びこれらにそれぞれ適当 のアルカリを加党たものを試料として所定の通電を行っ た. アルカリの添加量は次の如くして定めた.すなわち 先にク口ム鞦の研究第 3 報2 に述べたように先ず $0.1 \%$ $\left(\mathrm{Cr}_{2} \mathrm{O}_{3}\right)$ のクロム液 $200 \mathrm{cc}$ に $N / 10-\mathrm{NaOH}$ を一定量添 